\title{
FAKTOR -FAKTOR YANG MEMPENGARUHI PROSES INVOLUSI UTERUS PADA MASA NIFAS DIWILAYAH KERJA PUSKESMAS MANDALA KABUPATEN LEBAK PROPINSI BANTEN TAHUN 2016
}

\author{
Ninik Wahyuni*, Lisa Nurlatifah*
}

\begin{abstract}
Abstrak
Angka Kematian Ibu (AKI) di Indonesia akibat perdarahan post partum mempunyai peringkat tertinggi. Wilayah kerja Puskesmas Mandala masih terjadi kasus subinvolusi uterus akibat kurangnya pengetahuan ibu nifas tentang proses involusi uterus.

Setelah persalinan, kondisi tubuh ibu secara anatomi akan mengalami perubahan, salah satunya adalah kembalinya rahim pada ukuran semula. Proses ini disebut dengan involusi uterus (Ambarwati, 2010).

Penelitian penelitian ini bertujuan untuk menganalisis faktor-faktor yang mempengaruhi terjadinya proses involusi uterus selama masa nifas di wilayah kerja puskesmas Mandala Kabupaten Lebak Provinsi Banten. Jenis Penelitian yang digunakan observasional analitik dengan rancangan penelitian cross sectional, dengan analisis Data Univariat, bivariat dan multivariat, sample penelitian sebanyak 47 orang.

Hasil penelitian dari analisis univariat berdasarkan proses laktasi masih ditemukan ibu nifas yang memberikan laktasi kurang baik sebanyak 13 orang $(27,7 \%)$, mobilisasi terbatas sebanyak 6 orang $(12,8 \%)$, menu tidak seimbang sebanyak 4 orang $(8,5 \%)$, sebagian besar ibu nifas telah melahirkan anak lebih dari satu kali (multipara) sebanyak 29 orang $(61,7 \%)$, ibu nifas yang mengalami involusi yang tidak normal sebanyak 4 orang $(8,5 \%)$. Untuk hasil analisis bivariate variable laktasi, mobilisasi dan nutrisi, Secara bivariat diperoleh rata-rata $\mathrm{P}$ Value $=$ kurang dari $0,05(\mathrm{P}<\alpha)$ yang berarti terdapat hubungan yang signifikan dan sedangkan yang tidak berhubungan adalah paritas dengan hasil $\mathrm{P}$ Value $=$ lebih dari 0,05 $(\mathrm{P}>\alpha)$. Hasil analisis multivariate keempat variabel independen tidak signifikan memberikan pengaruh pada variable dependen dengan nilai $\mathrm{p}>0,05$. Faktor-faktor yang berhubungan dengan involusi uterus pada ibu nifas adalah laktasi, mobilisasi dan nutrisi, dan yang tidak berhubungan adalah paritas. analisis multivariate dari keempat variable yaitu (laktasi, mobilisasi, nutrisi, dan paritas ) ternyata tidak ada pengaruh signifikan dengan involusi uterus.
\end{abstract}

Kata kunci : laktasi, mobilisasi, nutrisi, paritas, involusi uterus.

*Dosen Jurusan Kebidanan Rangkasbitung Poltekkes Kemenkes Banten 


\section{Pendahuluan}

Masa Nifas (Puerperium) adalah masa setelah keluarnya plasenta sampai alat - alat reproduksi pulih seperti sebelum hamil dan secara normal masa nifas berlangsung selama 6 minggu atau 40 hari. (Ambarwati, 2010)

Setelah persalinan, kondisi tubuh ibu secara anatomi akan mengalami perubahan, salah satunya adalah kembalinya rahim pada ukuran semula. Proses ini disebut dengan involusi uterus. Ketika involusi berlangsung, pada tempat implantasi plasenta ditemukan banyak pembuluh darah yang terbuka sehingga resiko perdarahan post partum sangat besar.Hal ini terjadi jika otot-otot pada uterus tidak berkontraksi dengan baik untuk menjepit pembuluh darah yang terbuka.

Angka Kematian Ibu (AKI) di Indonesia akibat perdarahan post partum mempunyai peringkat tertinggi. Bila uterus pada ibu post partum mengalami kegagalan dalam involusi uterus maka akan menyebabkan terjadinya subinvolusi uterus yang dapat mengakibatkan perdarahan dan berlanjut hingga kematian.

Subinvolusi uteri adalah proses pengembalian uterus terlambat yang disebabkan karena adanya infeksi endometrium, adanya sisa plasenta, adanya bekuan darah, atau karena mioma uteri.
Faktor-faktor yang mempengaruhi proses involusi uterus adalah laktasi, mobilisasi, gizi/nutrisi dan paritas; oksitosin yang dihasilkan dari proses laktasi akan menyebabkan terjadinya kontraksi dan retraksi otot uterus. Mobilisasi akan membantu otot rahim bekerja dengan baik sehingga kontraksi uterus berjalan normal. Masa nifas membutuhkan tambahan kalori sebesar 500kkal/hari untuk menunjang proses laktasi dan involusi uterus. Hasil penelitian menunjukan bahwa semakin tinggi paritas maka makin cepat pengeluaran lochea tetapi karena fungsi otot rahim ibu multipara sudah menurun, maka proses involusi akan berjalan lambat. (Cuningham, 2007)

Puskesmas Mandala merupakan salah satu Fasilitas Pelayanan Kesehatan Masyarakat yang berada di Wilayah Kabupaten Lebak dan memiliki 6 Desa Binaan yaitu Desa Bojong Leles, Desa Kadu Agung Timur, Desa Tambak Bayah, Desa Kadu Agung Tengah, Desa Mekar Agung dan Desa Kadu Agung Barat. Pada tahun 2016 target persalinan di Puskesmas Mandala sebesar 693 Persalinan.

Dari hasil wawancara yang dilakukan pada 5 orang ibu nifas yang mengalami involusi uterus, diperoleh data bahwa ibu tidak memberikan ASI secara on deman, ibu juga tidak melengkapi menu gizi seimbang untuk ibu nifas dan membatasi mobilisasi. 


\section{Metoda}

Rancangan penelitian ini menggunakan metode cross sectional dimana data hanya diambil satu kali (one time approach) pada kelompok ibu nifas dengan variabel independen (laktasi, mobilisasi, nutrisi dan paritas) dan variabel dependen (proses involusi uterus).

Populasi target dalam penelitian ini adalah jumlah sasaran ibu bersalin di wilayah kerja Puskesmas Mandala pada bulan Agustus 2016 sebesar 53 persalinan.

\section{Hasil}

Distribusi karakteristik masing-masing variabel dapat dilihat pada tabel dibawah ini:

Tabel 1

Distribusi frekuensi ibu nifas berdasarkan proses laktasi

\begin{tabular}{|l|c|c|}
\hline \multicolumn{1}{|c|}{ LAKTASI } & F & $\%$ \\
\hline Baik & 34 & 72.3 \\
\hline Kurang Baik & 13 & 27.7 \\
\hline Total & 47 & 100 \\
\hline
\end{tabular}

Berdasarkan tabel 1 menunjukkan data masih ditemukan ibu nifas yang memberikan laktasi kurang baiksebanyak 13 orang $(27,7 \%)$.

Tabel 2

Distribusi frekuensi ibu nifas berdasarkan mobilisasi

\begin{tabular}{|l|c|c|}
\hline MOBILISASI & $\mathrm{F}$ & $\%$ \\
\hline Normal & 41 & 87.2 \\
\hline Terbatas & 6 & 12.8 \\
\hline Total & 47 & 100 \\
\hline
\end{tabular}

Berdasarkan tabel 2 menunjukkan data masih ditemukan ibu nifas yang melakukan mobilisasi terbatas sebanyak 6 orang $(12,8 \%)$.

Tabel 3

Distribusi frekuensi ibu nifas berdasarkan nutrisi

\begin{tabular}{|l|c|c|}
\hline \multicolumn{1}{|c|}{ NURTRISI } & F & $\%$ \\
\hline Seimbang & 43 & 91.5 \\
\hline Tidak Seimbang & 4 & 8.5 \\
\hline Total & 47 & 100 \\
\hline
\end{tabular}

Berdasarkan tabel 3 menunjukkan data masih ditemukan ibu nifas yang makan dengan menu tidak seimbang sebanyak 4 orang $(8,5 \%)$.

Tabel 4

Distribusi frekuensi ibu nifas berdasarkan Paritas

\begin{tabular}{|l|c|c|}
\hline PARITAS & F & $\%$ \\
\hline Primipara & 18 & 38.3 \\
\hline Multipara & 29 & 61.7 \\
\hline Total & 47 & 100 \\
\hline
\end{tabular}

Berdasarkan tabel 4 menunjukkan sebagian besar ibu nifas telah melahirkan anak lebih dari satu kali (multipara) sebanyak 29 orang $(61,7 \%)$.

Tabel 5

Distribusi frekuensi ibu nifas berdasarkan involusi uterus

\begin{tabular}{|l|c|c|}
\hline INVOLUSI UTERUS & $\mathrm{F}$ & $\%$ \\
\hline Normal & 43 & 91.5 \\
\hline Tidak normal & 4 & 8.5 \\
\hline Total & 47 & 100 \\
\hline
\end{tabular}


Berdasarkan tabel 5 menunjukkan masih ditemukan ibu nifas yang mengalami involusi uterus tidak normal sebanyak 4 orang $(8.5 \%)$.

Analisis bivariate dilakukan dengan menggunakan Chi-Square untuk melihat ada tidaknya hubungan antara variabel independen (laktasi, mobilisasi, nutrisi dan paritas) dan variabel dependen (involusi uterus) pada ibu nifas dengan tingkat kemaknaan (95\%) $\alpha=0,05$.

Tabel 6

Hubungan laktasi dengan involusi uterus pada ibu nifas

\begin{tabular}{|l|c|c|c|c|c|c|}
\hline \multirow{3}{*}{ Laktasi } & \multicolumn{3}{|c|}{ Involusi Uterus } & \multicolumn{2}{c|}{ TOTAL } \\
\cline { 2 - 6 } & \multicolumn{2}{|c|}{ Normal } & $\begin{array}{c}\text { Tidak } \\
\text { Normal }\end{array}$ & \multicolumn{2}{c}{} \\
\cline { 2 - 6 } & $\mathrm{F}$ & $\%$ & $\mathrm{~F}$ & $\%$ & $\mathrm{~F}$ & $\%$ \\
\hline Baik & 34 & 100 & 0 & 0.0 & 34 & 100 \\
\hline Kurang Baik & 9 & 69.2 & 4 & 30.8 & 13 & 100 \\
\hline TOTAL & 43 & 91.5 & 4 & 8.5 & 47 & 100 \\
\hline \multicolumn{6}{|c|}{ P value $=0,004$} \\
\hline \multicolumn{6}{|c|}{ OR $=1,4$} \\
\hline
\end{tabular}

Hasil analisis hubungan pada tabel 6 menunjukan bahwa kejadian involusi tidak normal lebih banyak $(30,8 \%)$ terjadi pada ibu dengan laktasi kurang baik bila dibandingkan dengan ibu dengan lakasi baik, tidak terdapat $(0,0 \%)$ yang mengalami involusi tidak normal.

Secara bivariat diperoleh $\mathrm{P}$ Value $=$ $0,004(\mathrm{P}<\alpha)$ yang berarti terdapat hubungan yang signifikan antara laktasi dengan involusi uterus.
Hasil analisis diperoleh nilai $\mathrm{OR}=$ 1,4 yang menunjukan bahwa ibu dengan laktasi kurang baik memiliki resiko 1,4 kali lebih tinggi mengalami involusi tidak normal bila dibandingkan dengan ibu nifas dengan laktasi yang baik.

\section{Tabel 7}

Hubungan antara mobilisasi dengan involusi uterus pada ibu nifas

\begin{tabular}{|l|c|c|c|c|c|c|}
\hline Mobilisasi & \multicolumn{3}{|c|}{ Involusi Uterus } & \multicolumn{2}{c|}{ TOTAL } \\
\cline { 2 - 7 } & \multicolumn{2}{|c|}{ Normal } & $\begin{array}{c}\text { Tidak } \\
\text { Normal }\end{array}$ & \multicolumn{2}{c|}{} \\
\cline { 2 - 7 } & $\mathrm{F}$ & $\%$ & $\mathrm{~F}$ & $\%$ & $\mathrm{~F}$ & $\%$ \\
\hline Normal & 41 & 100 & 0 & 0.0 & 41 & 100 \\
\hline Terbatas & 2 & 33.3 & 4 & 66.7 & 6 & 100 \\
\hline TOTAL & 43 & 91.5 & 4 & 8.5 & 47 & 100 \\
\hline \multicolumn{8}{|c|}{ P Value $=0,000$} \\
\hline \multicolumn{8}{|c|}{ OR $=3$} \\
\hline
\end{tabular}

Hasil analisis hubungan pada tabel 7 menunjukan bahwa kejadian involusi tidak normal lebih banyak $(66,7 \%)$ terjadi pada ibu dengan mobilisasi terbatas bila dibandingkan dengan ibu dengan mobilisasi normal, tidak terdapat $(0,0 \%)$ yang mengalami involusi tidak normal.

Secara bivariat diperoleh $\mathrm{P}$ Value $=$ $0,000(\mathrm{P}<\alpha)$ yang berarti terdapat hubungan yang signifikan antara mobilisasi dengan involusi uterus.

Hasil analisis diperoleh nilai $\mathrm{OR}=3$ yang menunjukan bahwa ibu dengan mobilisasi terbatas memiliki resiko 3 kali lebih tinggi mengalami involusi tidak normal bila dibandingkan dengan ibu nifas dengan mobilisasi normal. 
Tabel 8

Hubungan antara nutrisi dengan involusi uterus pada ibu nifas

\begin{tabular}{|l|c|c|c|c|c|c|}
\hline \multirow{3}{*}{ Nutrisi } & \multicolumn{4}{|c|}{ Involusi Uterus } & \multicolumn{2}{c|}{ TOTAL } \\
\cline { 2 - 6 } & Normal & \multicolumn{2}{c|}{$\begin{array}{c}\text { Tidak } \\
\text { Normal }\end{array}$} & \multicolumn{1}{c|}{} \\
\cline { 2 - 6 } & F & $\%$ & F & $\%$ & F & $\%$ \\
\hline Seimbang & 41 & 95.3 & 2 & 4.7 & 43 & 100 \\
\hline $\begin{array}{l}\text { Tidak } \\
\text { seimbang }\end{array}$ & 2 & 50.0 & 2 & 50.0 & 4 & 100 \\
\hline TOTAL & 43 & 91.5 & 4 & 8.5 & 47 & 100 \\
\hline \multicolumn{6}{|c|}{ OR Value $=0,031$} \\
\hline \multicolumn{6}{|c|}{ OR $=20,50$} \\
\hline
\end{tabular}

Hasil analisis hubungan pada tabel 8 menunjukan bahwa kejadian involusi tidak normal lebih banyak $(50,0 \%)$ terjadi pada ibu dengan nutrisi tidak seimbang porsi kurang bila dibandingkan dengan ibu dengan nutrisi seimbang porsi cukup $(4,7 \%)$ yang mengalami involusi tidak normal.

Secara bivariat diperoleh $\mathrm{P}$ Value $=$ $0,031(\mathrm{P}<\alpha)$ yang berarti terdapat hubungan yang signifikan antara nutrisi dengan involusi uterus.

Hasil analisis diperoleh nilai $\mathrm{OR}=$ 20,5 yang menunjukan bahwa ibu dengan nutrisi tidak seimbang porsi kurang memiliki resiko 20,5 kali lebih tinggi mengalami involusi tidak normal bila dibandingkan dengan ibu nifas dengan nutrisi seimbang porsi cukup.
Tabel 9

Hubungan antara paritas dengan involusi uterus pada ibu nifas

\begin{tabular}{|c|l|c|c|c|c|c|c|}
\hline \multirow{2}{*}{ No } & Paritas & \multicolumn{3}{|c|}{ Involusi Uterus } & \multirow{2}{*}{ TOTAL } \\
\cline { 3 - 7 } & & Normal & \multicolumn{2}{c|}{$\begin{array}{c}\text { Tidak } \\
\text { Normal }\end{array}$} & \multicolumn{2}{c}{} \\
\cline { 3 - 7 } & & $\mathrm{F}$ & $\%$ & $\mathrm{~F}$ & $\%$ & $\mathrm{~F}$ & $\%$ \\
\hline 1 & Primipara & 28 & 96.6 & 1 & 3.4 & 29 & 100 \\
\hline 2 & Multipara & 15 & 83.3 & 3 & 16.7 & 18 & 100 \\
\hline & TOTAL & 43 & 91.5 & 4 & 8.5 & 47 & 100 \\
\hline \multicolumn{9}{|c|}{$\mathrm{P}=0,150$} \\
\hline
\end{tabular}

Hasil analisis hubungan pada tabel 9 menunjukan bahwa kejadian involusi tidak normal lebih banyak $(16,7 \%)$ terjadi pada ibu dengan multipara bila dibandingkan dengan ibu primipara $(3,4 \%)$ yang mengalami involusi tidak normal.

Secara bivariat diperoleh $\mathrm{P}$ Value $=$ $0,150 \quad(\mathrm{P}>\alpha)$ yang berarti tidak terdapat hubungan yang signifikan antara paritas dengan involusi uterus.

Tabel 10

Pemodelan Akhir Hasil Analisis Regresi

Logistik

Variables in the Equation

\begin{tabular}{|c|c|c|c|c|c|c|c|c|}
\hline & \multirow[t]{2}{*}{ B } & \multirow[t]{2}{*}{ S.E. } & \multirow[t]{2}{*}{$\begin{array}{c}\text { Wal } \\
d\end{array}$} & \multirow[t]{2}{*}{ df } & \multirow[t]{2}{*}{ Sig. } & \multirow[t]{2}{*}{$\begin{array}{l}\text { Exp } \\
\text { (B) }\end{array}$} & \multicolumn{2}{|c|}{$\begin{array}{c}95 \% \text { C.I.for } \\
\text { EXP(B) }\end{array}$} \\
\hline & & & & & & & Lower & Upper \\
\hline Kat_laktasi & -18.016 & 7404.808 & .000 & 1 & 998 & .000 & .000 & \\
\hline Kat_mobilisasi & -20.055 & 6390.564 & .000 & 1 & 997 & .000 & .000 & \\
\hline Kat_nutrisi & -18.506 & 7421.906 & .000 & 1 & .998 & .000 & .000 & \\
\hline Kat_paritas & -.579 & 6049.691 & .000 & 1 & 1.00 & .561 & .000 & \\
\hline Constant & 19.199 & 7421.906 & .000 & 1 & 998 & $\begin{array}{l}2178 \\
0213\end{array}$ & & \\
\hline & & & & & & 5.72 & & \\
\hline
\end{tabular}

a. Variable(s) entered on step 1: Kat_laktasi, Kat_mobilisasi, Kat_nutrisi,

Kat_paritas. 
Berdasarkan hasil uji regresi logistik pada tabel 10 diketahui bahwa keempat variabel independen tidak signifikan memberikan pengaruh pada variable dependen dengan nilai $\mathrm{p}>0,05$. Mungkin karena ada faktor lain yang berpengaruh terhadap involusi uterus masa nifas yang tidak diteliti pada penelitian ini.

\section{Pembahasan}

\section{Ibu nifas berdasarkan proses laktasi}

Pada proses laktasi (menyusui) ada reflek let down dari isapan bayi, merangsang hipofise posterior mengeluarkan hormone oksitosin yang oleh darah hormone ini diangkat menuju uterus dan membantu uterus berkontraksi sehingga proses involusi uterus terjadi. (Elisabeth Siwi, 2015)

\section{Ibu nifas berdasarkan mobilisasi}

Aktivitas otot-otot adalah kontraksi dan retraksi dari otot-otot setelah anak lahir, yang diperlukan untuk menjepit pembuluh darah yang pecah karena adanya pelepasan plasenta dan berguna untuk mengeluarkan isi uterus yang tidak diperlukan, dengan adanya kontraksi dan retraksi yang terus menerus ini menyebabkan terganggunya perdaran darah dalam uterus yang mengakibatkan jarigan otot kekurangan zatzat yang diperlukan, sehingga ukuran jaringan otot-otot tersebut menjadi kecil. (Elisabeth Siwi, 2015).

\section{Ibu nifas berdasarkan nutrisi}

Status gizi adalah tingkat kecukupan gizi seseorang yang sesuai dengan jenis kelamin dan usia. Status gizi yang kurang pada ibu postpartum maka pertahanan pada dasar ligamentum latum yang terdiri dari kelompok infiltrasi sel-sel bulat yang disamping mengadakan pertahanan terhadap penyembuhan kuman bermanfaat pula untuk menghilangkan jaringan nefrotik, pada ibu postpartum dengan status gizi yang baik akan mampu menghindari serangan kuman sehingga tidak terjadi infeksi dalam masa nifas dan mempercepat proses involusi uterus.(Elisabeth Siwi, 2015)

\section{Ibu nifas berdasarkan paritas}

Paritas mempengaruhi involusi uterus, otot-otot yang terlalu sering teregang memerlukan waktu yang lama.(Elisabeth Siwi, 2015)

\section{Ibu nifas berdasarkan involusi uterus}

Involusi atau pengerutan uterus merupakan suatu proses kembalinya uterus ke keadaan sebelum hamil. Uterus ibu yang baru melahirkan jika diraba dari luar tinggi fundus uteri kira-kira 1 jari dibawah pusat, sedangkan beratnya kira-kira 1 kilogram. Hal ini disebabkan oleh banyaknya darah dari dinding rahim mengalir dalam pembuluh-pembuluh darah yang membesar.Sampai hari ke-2 uterus masih membesar dan setelah itu berangsur 
angsur menjadi kecil.Pada hari ke-3 tinggi fundus uteri kira-kira 2 atau 3 jari dibawah pusat.Hari ke- 6 berada pada pertengahan simfisis-pusat.Hari ke-7 kira-kira 2 atau 3 jari di atas simfisis.Hari ke- 9 kira-kira 1 jari di atas simfisis.Dan setelah hari ke-10 biasanya uterus tidak teraba lagi dari luar.Semua ini disebabkan karena pemberian darah didalam rahim jauh berkurang, sehingga otot-otot menjadi kecil.

Pada akhir kala III persalinan, uterus berada di garis tengah, kira-kira $2 \mathrm{~cm}$ (2jari) dibawah umbilicus dengan bagian fundus bersandar promontorium sakralis.(Ambarwati, 2009).

\section{Hubungan antara laktasi dengan involusi uterus pada ibu nifas}

Inisiasi Menyusui dini dapat menyebabkan adanya rangsangan dan dikeluarkannya hormone antara lain oksotocin yang berfungsi selain merangsangotot-otot polos payudara,juga menyebabkan terjadinya kontraksi dan retraksi otot uterus. Hal ini akan menekan pembuluh darah yang mengakibatkan berkurangnya suplai darah keuterus sehingga mengurangi perdarahan.Involusi uterus pada wanita yang menyusui lebih cepat daripada tidak menyusui.(Friske wulan,Siti fatonah Pengaruh menyusui terhadap penurunan tinggi Fundus Uteri pada ibu post partum pimi gravida di
RSUD Dr.R.Sosodoro djati koesoemo Bojonegoro 2015)

\section{Hubungan antara mobilisasi dengan involusi uterus pada ibu nifas}

Mobilisasi merupakan suatu gerakan yang dilakuhirkan kan bertujuan untuk merubah posisi semula dari ibu berbaring,miring-miring,duduk sampai berdiri sendiri setelah beberapa jam melahirkan Tujuan memperlancar pengeluaran lochea (sisa darah nifas),mempercepat involusi,melancarkan fungsi organ gastrointestinal dan organ perkemihan ,memperlancar peredaran $\begin{array}{lll}\text { sirkulasi darah sesuai } & \end{array}$ dengan(Moechtar,2012) dengan bergerak akan merangsang peristaltic usus,kandung kemih kembali normal.Aktifitas ini juga membantu mempercepat organ tubuh bekerja seperti semula.

\section{Hubungan antara nutrisi dengan involusi uterus pada ibu nifas}

Ibu nifas memerlukan diet untuk mempertahankan tubuh terhadap infeksi,mencegah konstipasi dan untuk memulai proses pemberian ASI (Depkes 2004). Pada saat nifas sebaiknya makan makanan yang mengandung protein,banyak cairan,sayur-sayuran dan buah-buahan (Mochtar,2002).

\section{Hubungan antara paritas dengan involusi uterus pada ibu nifas}

Paritas mempengaruhi proses involus uterus. Paritas pada ibu multipara 
cenderung menurun kecepatannya dibandingkan ibu primipara karena primi kekuatan kontraksi uterus lebih tinggi dan uterus teraba lebih keras,sedangkan pada multipara kontraksi dan retraksi uterus berlangsung lebih lama begitu juga ukuran uterus pada ibu primipara ataupun multipara memiliki perbedaan sehingga memberikan pengaruh terhadap proses involusi.

Sampai dengan paritas tiga rahim ibu bias kembali seperti sebelum hamil. setiap kehamilan rahim mengalami pembesaran,terjadi peregangan otot-otot rahim selama 9 bulan kehamilan semakin sering ibu hamil dan melahirkan semakin sering ibu hamil dan melahirkan semakin dekat jarak kehamilan dan persalinan,elastisitas uterus semakin tergangu,akibatnya uterus tidak berkontraksi secara sempurna dan mengakibatkan lamanya proses pemulihan organ reproduksi (involusi) pasca salin.

Hasil penelitian mengungkapkan bahwa paritas ibu mempengaruhi lamanya pengeluaran lochea semakin tinggi paritas semakin cepat proses pengeluaran lochea.Akan tetapi karena kondisi otot rahim pada ibu bersalin multipara cenderung sudah tidak terlalu kuat maka proses involusi berjalan lebih lambat.(De saraswati,2014).

Dalam penelitian ini tidak terdapat hubungan yang signifikan antara paritas dengan involusi uterus karena sebagian besar sampel penelitian dengan multipara 2-3 persalinan, sedangkan paritas yang akan menghambat involusi uterus adalah persalinan lebih dari tiga kali.

\section{Pemodelan Akhir Hasil Analisis \\ Regresi Logistik}

Analisis mutivariat dilakukan untuk mengetahui pengaruh tiap-tiap variable bebas secara bersam-sama terhadap variable terikat. Sebelum dianalisis terlebih dahulu dilakukan seleksi pada variable bebas dengan pertimbangan substansi hanya yang mempunyai nilai $\mathrm{p} \leq 0,25$ yang dimasukan dalam model. Maka berdasarkan analisis bivariate, variable yang masuk ke dalam model regresi adalah laktasi, mobilisasi, nutrisi dan paritas. Selanjutnya dilakukan analisis regresi logistik dengan metode enter. Dengan hasil pemodelan regresi yang baik diharapkan dapat mendeskripsikan variable-variabel yang berpengaruh terhadap involusi uterus pada ibu nifas.hasil uji regresi logistik pada tabel 4.10 diketahui bahwa keempat variabel independen tidak signifikan memberikan pengaruh pada variable dependen dengan nilai $\mathrm{p}>0,05$. Mungkin karena ada faktor lain yang berpengaruh terhadap involusi uterus masa nifas yang tidak diteliti pada penelitian ini.

\section{Simpulan}

Berdasarkan hasil analisis data dan pembahasan teori factor-faktor yang 
mempengaruhi involusi uterus pada ibu nifas, dapat ditarik kesimpulan sebagai berikut :

Faktor-faktor yang berhubungan dengan involusi uterus pada ibu nifas adalah laktasi, mobilisasi dan nutrisi, dan yang tidak berhubungan adalah paritas.

Setelah dilakukan analisis multivariate dari keempat variable yaitu (laktasi,mobilisasi,nutrisi,dan paritas) ternyata tidak ada pengaruh signifikan dengan involusi uterus.

\section{Daftar Pustaka}

Alimatul Hidayat, Aziz. 2012. Metode Penelitian Kebidanan \& Teknik Analisis Data. Jakarta : Salemba Medika

Ambarwati. 2009. Asuhan Kebidanan Masa Nifas. Jakarta: TIM

Azzahro, Riffa. Konsep Dasar Masa Nifas. www.academia.edu/10728391. diakses pada tanggal 20 juni 2016.

Chandra, Budiman. 2008. Metodologi

Penelitian Kesehatan. Jakarta : EGC.

Dwi Apriliasari. 2015. Hubungan Usia dan Paritas dengan Kejadian Involusi Uterus di BPS Mojokerto. KTI D III Kebidanan Poltekkes Majapahit. Easterzxcngulz, Konsep Dasar Masa Nifas. http://easterngulz.wordpress.com.
Diakses pada tanggal 4 Desember 2013.

Ferdina Fitriana Mayasari. 2015. Faktorfaktor yang Mempengaruhi Involusi Uterus. Semarang. TESIS Pasca Sarjana Universitas Muhamadiyah Semarang.

Hartono, Sutanto Priyo. 2013. Statistik Kesehatan. Jakarta : Raja GrafindoPersada.

Maryunani, Anik. 2009. Asuhan Kebidanan masa Nifas. Jakarta: TIM.

Nanny LiaDewi, Vivian. 2013. Asuhan Kebidanan Pada Ibu Nifas. Jakarta : Salemba Medika.

Notoadmojo, Soekidjo. 2010. Metodologi

Penelitian Kesehatan. Jakarta : Rineka Cipta.

Nugroho, Taufan, dkk. 2011. Asuhan Kebidanan 3 (Nifas). Yogyakarta : Yumed.

Riadi, Muchlisin. Involusi Organ Reproduksi.

www.kajianpustaka.com/2012/11/inv olusi-organ-reproduksi.html. diakses pada tanggal 10 November 2012 Rukiyah, Ai Yeyeh, dkk. 2011. Asuhan Kebidanan III (Nifas). Jakarta: TIM. Saleha, Sitti. 2013. Asuhan Kebidanan Pada Masa Nifas. Jakarta: Salemba Medika.

Siwi Walyani, Elisabeth. 2015. Asuhan Kebidanan Masa Nifas dan 
Menyusui. Yogyakarta: Pustaka baru press.

Sudaryono. 2011. Metode Penelitian

Pendidikan. Dinas Pendidikan

Provinsi Banten : Banten.

Yanti, Damai dan Sundawati, Dian. 2011.

Asuhan Kebidanan Masa Nifas.

Bandung: Refika Aditama. 